\title{
Pengawasan dan Penegakan Hukum terhadap Sertifikasi dan Labelisasi Halal Produk Pangan
}

\author{
KN. Sofyan Hasan \\ Fakultas Hukum Universitas Sriwijaya Palembang-Sumatera Selatan \\ Jln. Palembang-Prabumulih Km. 32 Inderalaya Kabupaten Ogan Ilir \\ kn.sofyan_hasan@yahoo.co.id
}

\begin{abstract}
The primary problem in this study is how to law enforcement and the protection of consumer's rights against the certification and labeling of halal products according to UUJPH. The second problem to consider is the factors that causing young enterpreneurs to delay certification and halal product labeling on their products. This is a normative juridical research with a complementary juridical empirical data. The study points out that: first, until now there has been no law enforcement and no collective protection of consumer rights on the certification and labeling of halal products. To complicate matters, there is lack of coordination between ministries and agencies by MORA RI. Second, some of the factors that cause the enterpreneurs to delay halal certification on their products are the facts that: i) UUJPH cannot be implemented operationally because the Government Regulation (PP) has not been issued; ii) BPJPH which is the mandate of UUJPH has not been established; iii) Business actors find it difficult to certify some kinds of their products, such as pharmaceutical products since the raw materials are imported from abroad; iv) There is a reatively poor public awareness of consumers of halal products since they do not prioritize halal factor in selecting and purchasing a product.
\end{abstract}

Key wors: Protection, consumer, certification, halal labeling, and halal products

\begin{abstract}
Abstrak
Pokok permasalahan dalam penelitian ini; pertama, bagaimana upaya penegakan hukum dan perlindungan hak konsumen terhadap sertifikasi dan labelisasi produk halal menurut UUJPH. Kedua, faktor-faktor apa saja yang menyebabkan pelaku usaha menunda melakukan sertifikasi dan labelisasi produk halal atas produk-produk mereka. Penelitian ini merupakan penelitian normatif dan sebagai (data) pendukung dilengkapi dengan empiris. Hasil penelitian menyimpulkan bahwa: pertama, hingga saat ini belum ada penegakan hukum dan perlindungan hak konsumen secara kolektif atas sertifikasi dan labelisasi produk halal tersebut. Serta belum adanya koordinasi lintas kementerian dan lembaga oleh Kemenag RI. Kedua, beberapa faktor yang menyebabkan para pelaku usaha menunda melakukan sertifikasi halal atas produk-produk mereka: i) UUJPH belum bisa dilaksanakan secara operasional sebab Peraturan Pemerintah (PP) yang belum dikeluarkan; ii) BPJPH yang merupakan amanat UUJPH juga belum didirikan; iii) Pelaku usaha merasa kesulitan untuk menyertifikasi beberapa jenis produk mereka, misalnya produk farmasi. Kesulitan produk farmasi yang mengimpor bahan baku dari luar negeri; iv) Kesadaran masyarakat selaku konsumen terhadap produk halal belum begitu baik. Faktor kehalalan suatu produk belum menjadi faktor utama dalam memilih dan membeli suatu produk.
\end{abstract}

Kata kunci: Perlindungan, konsumen, sertifikasi, labelisasi halal, dan produk halal 


\section{Pendahuluan}

Menurut syari'at Islam, memakan, meminum atau menggunakan produk halal dikategorikan sebagai perilaku ibadah. Selanjutnya dikatakan bahwa mengkonsumsi produk halal menurut keyakinan agama (Islam) dan/atau demi kualitas hidup dan kehidupan, merupakan hak warga negara yang dijamin oleh Undang-Undang Dasar (UUD) $1945 .{ }^{1}$ K.H. Ma'ruf Amin, ${ }^{2}$ menyatakan bahwa di dalam ayat Al-Qur'an Allah telah memerintahkan kita untuk mengkonsumsi yang halal dan meninggalkan yang haram. Seperti ditegaskan dalam ayat dengan makna "Dan makanlah yang halal lagi baik dari apa yang Allah telah rezekikan kepadamu, dan bertakwalah kepada Allah yang kamu beriman kepada-Nya." (Q.S.Al-Maidah [5]:88). Juga dalam ayat lain yang artinya: "Maka makanlah yang halal lagi baik dari rezeki yang telah diberikan Allah kepadamu; dan bersyukurlah (atas) nikmat Allah, jika kamu hanya kepada-Nya saja menyembah." (Q.S. An-Nahl [16]:114).

Kehati-hatian konsumen dalam memilih produk halal menjadi sangat penting. Apalagi Undang-Undang Nomor 33 Tahun 2014 tentang Jaminan Produk Halal (UUJPH) sudah ditetapkan sejak 17 Oktober 2014. Dalam UUJPH ditegaskan bahwa kewajiban bersertifikat halal atas produk yang beredar di Indonesia berlaku hingga lima tahun sejak undang-undang (UU) ini diundangkan. Data Badan Pengawasan Obat dan Makanan (BPOM) Indonesia pada tahun 2005 menunjukkan bahwa produk yang telah meminta pencantuman tanda halal tidak lebih dari 2.000 produk. Sementara data dari Majelis Ulama Indonesia (MUI) menunjukkan bahwa permohonan sertifikasi halal selama 15 tahun terakhir (1994-2009) tidak lebih dari 15.689 sertifikat, 42.620 produk dari 870 produsen di Indonesia. ${ }^{3}$ Ahmadi Miru, ${ }^{4}$ menyatakan bahwa produsen dalam kondisi tertentu kurang mempunyai tanggung jawab sosial, atau biro iklan (pelaku usaha periklanan) tidak taat pada kode etik profesionalisme untuk melakukan persuasif kepada konsumen tidak

${ }^{1}$ Mashudi, Konstruksi Hukum dan Respon Masyarakat terbadap Sertifikasi Produk Halal (Studi Socio-Legal terbadap Lembaga Pengkajian Pangan, Obat-obatan dan Kosmetika Majelis Ulama Indonesia), Program Doktor Ilmu Hukum Universitas Diponegoro, Semarang, 2011, hlm. 1.

${ }^{2}$ LP POM MUI. 2011. Jurnal Halal: Menentramkan Umat. No. 88 Th. XIV, hlm. 2.

${ }^{3}$ Mashudi, Op. Cit., hlm. 18-19. Lihat juga LP POM MUI, Jurnal Halal: Menentramkan Umat, Nomor 81, Tahun XIII, 2010, hlm. 5.

${ }^{4}$ Ahmadi Miru, Prinsip-prinsip Perlndungan Hukum bagi Konsumen di Indonesia, Raja Grafindo Persada, Jakarta, 2011, hlm. 3-4. 
dengan cara memberikan informasi yang benar tentang produk yang dipasarkan, melainkan menggunakan segala cara agar masyarakat mau membeli barang-barang produk suatu perusahaan yang dipromosikan. Kondisi konsumen yang banyak dirugikan, memerlukan peningkatan upaya melindunginya atau perlindungan hak, sehingga hak-hak konsumen dapat ditegakkan. Namun sebaliknya, perlu diperhatikan bahwa dalam memberikan perlindungan hak kepada konsumen, tidak boleh justru mematikan usaha produsen, karena keberadaan produsen merupakan suatu yang esensial dalam perekonomian negara. Karena itu, upaya terpenting dalam memberikan perlindungan kepada konsumen adalah melalui peraturan perundangundangan. ${ }^{5} \mathrm{Hal}$ ini sangat sejalan dengan pengertian jaminan produk halal itu sendiri. Karena yang dikatakan Jaminan Produk Halal yang selanjutnya disingkat JPH adalah kepastian hukum terhadap kehalalan suatu Produk yang dibuktikan dengan Sertifikat Halal. ${ }^{6}$ Sertifikat Halal adalah pengakuan kehalalan suatu produk yang dikeluarkan oleh BPJPH berdasarkan fatwa tertulis yang dikeluarkan oleh MUI.7 Untuk mencapai semua itu, perlu diselenggarakan suatu Penyelenggaraan Pangan ${ }^{8}$ yang dilakukan untuk memenuhi kebutuhan dasar manusia yang memberikan manfaat secara adil, merata, dan berkelanjutan dengan berdasarkan pada Kedaulatan Pangan, Kemandirian Pangan, dan Ketahanan Pangan. ${ }^{9}$ Penjelasan UU No. 18 Tahun 2012 tentang Pangan (selanjutnya disingkat UU Pangan) menyatakan bahwa Pelaku Usaha Pangan dalam melakukan Produksi Pangan harus memenuhi berbagai ketentuan mengenai kegiatan atau proses Produksi Pangan sehingga tidak beresiko merugikan atau membahayakan kesehatan manusia. Pemerintah berwenang untuk menetapkan persyaratan tentang komposisi pangan tersebut. Setiap orang yang memproduksi pangan untuk diedarkan perlu dibebani tanggung jawab, terutama apabila pangan yang diproduksinya menyebabkan baik kerugian pada kesehatan manusia maupun kematian orang yang mengkonsumsi pangan tersebut. ${ }^{10}$ Kegiatan produksi

${ }^{5}$ Ibid., hlm. 5.

${ }^{6}$ Pasal 1 angka 5 Undang-Undang Republik Indonesia Nomor 33 Tahun 2014 tentang Jaminan Produk Halal (UUJPH).

7 Pasal 1 angka 10 UUJPH.

8Penyelenggaraan Pangan adalah kegiatan perencanaan, peleksanaan, dan pengawasan dalam penyediaan, keterjangkauan, pemenuhan konsumsi Pangan dan Gizi, serta Kemanan Pangan dengan melibatkan peran serta masyarakat yang terkoordinasi dan terpadu (Pasal 1 angka 14 UU Nomor 18 Tahun 2012 tentang Pangan).

${ }^{9}$ Dirjen Bimas Islam dan Penyelenggaraan Haji. Op. Cit., hlm. 310-311.

${ }^{10}$ Ibid., hlm. 311-312. 
merupakan respons terhadap kegiatan konsumsi, atau sebaliknya. Produksi adalah kegiatan menciptakan suatu barang atau jasa, sementara konsumsi adalah pemakaian atau pemanfaatan hasil produksi tersebut. ${ }^{11}$ Dalam prosedurnya, halal tidak hanya berkutat pada masalah penggunaan bahan, namun juga sarana distribusi, transportasi, dan penyimpanan. ${ }^{12}$ Kustantinah, ${ }^{13}$ menjelaskan bahwa menurut data di Badan POM, sampai medio September 2010, persetujuan pencantuman Tanda/Label Halal berdasarkan Sertifikat Halal yang masih berlaku, 2009 berjumlah 2.799 produk. Selain dari itu sekitar 40.000-an registrasi produk oleh perusahaan ke Badan POM, hanya sejumlah 7294 produk yang diajukan perusahaan untuk pendaftaran dan mendapatkan label halal. Dengan demikian, hanya sekitar $15 \%$ dari seluruh produk yang dihasilkan perusahaan dalam negeri, yang diajukan registrasinya untuk mendapatkan tanda atau label halal, sesuai dengan prosedur yang telah ditetapkan dalam ketentuan perundang-undangan yang berlaku. Apalagi sekarang ini produkproduk yang beredar, selain semakin banyak juga bervariatif, dan yang tidak kalah pentingnya produk-produk luar negeri semakin membanjiri pasar Indonesia. ${ }^{14}$

Banyaknya pangan yang tersebar di masyarakat tanpa mengindahkan ketentuan tentang pencantuman label halal dinilai sudah meresahkan. Label dan iklan pangan yang tidak jujur dan/atau menyesatkan berakibat buruk terhadap perkembangan kesehatan manusia. ${ }^{15}$ Sementara pelabelan halal pangan, selama ini, baru merupakan kewajiban jika produsen/importir menyatakan halal bagi umat Islam. ${ }^{16}$ Label yang dimaksud dapat berupa keterangan nama barang, ukuran, netto, komposisi, aturan pakai, tanggal pembuatan, akibat sampingan, nama dan alamat pelaku usaha, keterangan halal, serta keterangan lain untuk penggunaan yang menurut ketentuan harus dibuat. ${ }^{17}$ Label Halal yang merupakan

${ }^{11}$ Lihat Sri Rejeki Hartono. Dkk, Kamus Hukum Ekonomi, Ghalia Indonesia, Jakarta, 2010, hlm. 90.

12 LP POM MUI. 2009. Jurnal Halal: Menentramkan Ummat. No. 78 Th. XII, hlm. 14.

${ }^{13}$ LP POM MUI. 2011. Jurnal Halal: Menentramkan Umat. No. 88 Th. XIV, hlm. 74.

${ }^{14}$ Wawancara dengan Rindit Pembayun selaku Direktur LP POM MUI Sumatera Selatan dan juga sebagai Guru Besar Ilmu Pangan Fakultas Pertanian Universitas Sriwijaya Palembang, di Palembang pada 15 Agustus 2013.

15Departemen Agama, Petunjuk Teknis Pedoman Sistem Produksi Halal, Dirjen Bimas Islam dan Penyelenggaraan Haji, 2003, hlm. 455.

${ }^{16}$ Ahmad Miru dan Sutarno Yodo, Hukum Perlindungan Konsumen, PT. Raja Grafindo Persada, Jakarta, 2004, hlm. 80 .

${ }^{17}$ Undang-Undang Nomor 8 Tahun 1999 tentang Perlindungan Konsumen (Lembaran Negara Nomor 42, Tambahan Lembaran Negara Nomor 3821, Pasal 8 ayat (1) huruf h dan i). 
tanda kehalalan suatu Produk ${ }^{18}$ bisa dicantumkan jika pelaku usaha sudah mendapatkan sertifikat halal yang sebelumnya diterbitkan oleh LPPOM MUI, sekarang dengan UUJP diterbitkan oleh BPJPH sebagimana ditentukan pada Pasal 33 ayat (6); Pasal 34 ayat (1) UUJPH. Sertifikat Halal adalah pengakuan kehalalan suatu Produk yang dikeluarkan oleh BPJPH berdasarkan fatwa halal tertulis yang dikeluarkan oleh MUI.19

Untuk memperoleh sertifikat halal pelaku usaha terlebih dahulu mengajukan permohonan secara tertulis kepada $\mathrm{BPJPH}^{20}$ yang harus dilengkapi dengan persyaratan: a) data Pelaku Usaha; b).nama dan jenis Produk; c).daftar Produk dan Bahan yang digunakan; dan d). proses pengolahan Produk. ${ }^{21}$ Pada Pasal 29 ayat (3) UUJPH menegaskan bahwa ketentuan lebih lanjut mengenai tata cara pengajuan permohonan Sertifikat Halal diatur dalam Peraturan Menteri.

Sebagaimana ditegaskan pada Pasal 49 UUJPH bahwa pengawasan terhadap Jaminan Produk Halal (JPH) dilaksanakan oleh BPJPH. Jika pelaku usaha melanggar ketentuan Pasal 25 huruf b UUJPH dikenakan sanksi pidana dengan pidana penjara paling lama 5 (lima) tahun atau pidana denda paling banyak Rp. 2 . 000.000.000.00.22

Sementara umumnya konsumen masih lemah dalam berbagai aspek, dan di sisi lain pelaku usaha tidak jujur dan atau menyesatkan, sehingga banyak produk pangan yang tersebar di masyarakat tanpa mengindahkan ketentuan tentang pencantuman lebel halal. ${ }^{23} \mathrm{Hal}$ ini disebabkan, antara lain karena faktor pengawasan masih belum optimal apalagi mengingat BPJPH dibebani dengan tugas dan fungsi selain pengawasan. Padahal seyogyanya ada badan yang khusus menangani pengawasan. Karena tanpa pengawasan yang tegas akan terasa kurang efektif regulasi yang telah diberlakukan. Apalagi Peraturan Pemerintah terhadap UUJPH hingga kini belum diterbitkan. Majalah Jurnal Halal melakukan survei pada 2007 untuk produkproduk yang mencantumkan label halal tanpa sertifikat halal. Survei tersebut

${ }^{18}$ Pasal 1 angka 11 Undang-Undang Republik Indonesia Nomor 33 Tahun 2014 tentang Jaminan Produk Halal (UUJPH).

${ }^{19}$ Pasal 1 angka 10 UUJPH.

${ }^{20}$ Menurut Ketentuan Pasal 59 UUJPH, sebelum BPJPH dibentuk, pengajuan permohonan perpanjangan Sertifikat Halal dilakukan sesuai dengan tata cara yang berlaku sebelum Undang-Undang ini diundangkan.

${ }^{21}$ Pasal 29 ayat (1) dan (2) UUJPH.

22 Pasal 61 PP Nomor 69 Tahun 1999 tentang Label dan Iklan Pangan.

23 Penjelasan Umum PP Nomor 69 Tahun 1999 tentang Label dan Iklan Pangan. 
menunjukkan masih banyak produk yang mencantumkan label halal tapi belum memiliki sertifikat halal. Lalu ditemukan pula ada perusahaan yang telah mencantumkan label halal pada semua produk di perusahaannya, padahal mereka baru mendapatkan sertifikat halal hanya untuk satu produk saja. ${ }^{24}$

Pengelola industri kecil sebagian tidak tahu bahwa produknya tersebut harus mencantumkan label halal. ${ }^{25}$ Terdapat banyak produk yang mencantumkan label halal tapi belum mendapatkan sertifikat halal. Kasus Desember 2012 berdasarkan survei yakni berbagai jenis bakso yang memiliki label halal akan tetapi mengandung bahan yang tidak memenuhi kriteria dalam memperoleh label halal di Indonesia. Ditemukan bakso tersebut di produksi pada jasa penggilingan daging untuk pedagang bakso di Pasar Cipete, Jakarta Selatan. ${ }^{26}$

Berdasarkan laporan warga, Dinas Peternakan Perikanan dan Kelautan, sudah mengadakan razia bakso oplosan daging sapi dan babi hutan. Padahal bakso tersebut sudah memiliki label halal. Hasil sampel bakso yang ditemukan mengandung daging babi hutan. Razia tersebut di Pasar Anyar Bahari, Tanjungpriok, Jakarta Utara dan di Jakarta Barat, bakso oplosan ditemukan di Pasar Puri, Pasar Grogol, dan Pasar Kopro. ${ }^{27}$

Berdasarkan contoh kasus-kasus di atas, seharusnya berbagai pihak terkait dari pemerintah harus mengadakan pengawasan lebih ketat dan menerapkan sanksi yang tegas sebagimana sudah diamanatkan UUJPH apabila terjadi kecurangan dalam pencantuman label halal karena hal ini sangat merugikan konsumen muslim.

\section{Rumusan Masalah}

Berdasarkan uraian yang telah dikemukakan di atas, dapat dirumuskan pokok permasalahan dalam penelitian ini yaitu: pertama, bagaimanakah upaya penegakan hukum dan perlindungan hak konsumen terhadap Sertifikasi dan

24“"Label Halal tanpa Sertifikat”, source http://m.republika.co.id/berita/shortlink/17092, diakses tanggal 10 Februari 2013.

${ }^{25}$ LPPOM MUI, Panduan Umum Sistem Jaminan Halal LP-POM MUI, Jakarta : LPPOM MUI, 2008, hlm. 26

26"MUI Desak Pengoplosan daging sapi dengan babi ditindak", source: http://www.metrotvnews.com/ $\mathrm{read} /$ news/2012/12/14/117668/MUI-Desak-Pengoplos-Daging-Sapi-dengan-Babi-Ditindak/6, di akses tanggal 12 Maret 2013.

27“Bakso Oplosan Daging Babi buat Resah Warga" source: http://www.metrotvnews.com/read/ newsvideo/2012/12/14/166459/Bakso-Oplosan-Daging-Babi-Buat-Resah-Warga/6, di akses tanggal 9 Mei 2013. 
Labelisasi Produk Halal menurut UUJPH? Kedua, faktor-faktor apa saja yang menyebabkan pelaku usaha menunda melakukan sertifikasi dan labelisasi produk halal atas produk-produk mereka?

\section{Tujuan Penelitian}

Adapun tujuan penelitian ini adalah untuk mengetahui: pertama, upaya penegakan hukum dan perlindungan hak konsumen terhadap sertifikasi dan labelisasi produk halal menurut UUJPH. Kedua, faktor-faktor yang menyebabkan pelaku usaha menunda melakukan sertifikasi dan labelisasi produk halal atas produkproduk mereka.

\section{Metode Penelitian}

Metode penelitian yang digunakan dalam penelitian ini ialah yuridis normative. Pengumpulan data dilakukan dengan studi kepustakaan dengan pendekatan perundang-undangan dan sebagai (data) pendukung dilengkapi dengan data empiris berupa wawancara. Data yang diperoleh melalui studi kepustakaan dianalisis secara kualitatif.

\section{Hasil Penelitian dan Pembahasan}

Penegakan Hukum dan Perlindungan Hak Konsumen terhadap Sertifikasi dan Labelisasi Produk Halal

Pengaturan penegakan hukum dan perlindungan konsumen di Indonesia sebenarnya telah tercantum dalam pembukaan Undang-Undang Dasar Negara Kesatuan Republik Tahun 1945 (UUD 1945) Alenia IV yang mengamantkan bahwa negara Indonesia melindungi segenap bangsa Indonesia dan seluruh tumpah darah Indonesia. Sehingga sudah jelas sebagai bangsa Indonesia, konsumen layak untuk mendapatkan perlindungan hukum.

Lahirnya organisasi konsumen di Indonesia dilatarbelakangi oleh banyaknya permasalahan yang memprihatinkan dan merugikan konsumen, 
sementara posisi konsumen sangat lemah. ${ }^{28}$ Masalah perlindungan konsumen baru mulai terdengar pada 1970-an yang ditandai dengan lahirnya Yayasan Lembaga Konsumen Indonesia (YLKI) pada Mei 1973. Sejarahnya, pada awalnya yayasan ini berkaitan dengan rasa mawas diri terhadap promosi yang memperlancar barangbarang dalam negeri.

Selain dari itu, karena posisi konsumen yang lemah maka harus dilindungi oleh hukum. Tujuan dari hukum itu adalah untuk memberikan perlindungan maupun pengayoman kepada masyarakat. Masyarakat merasa kurang bahagia bila hukum hanya melindungi dan memberi keleluasaan kepada individu dan tidak memperhatikan kebahagiaan masyarakat. ${ }^{29}$ Hukum konsumen dan hukum perlindungan konsumen merupakan dua bidang hukum yang sulit untuk dipisahkan dan ditarik batasannya.

Pembicaraan mengenai masalah penegakan hukum secara umum adalah masalah kepatuhan atau ketaatan hukum. Hal ini disebabkan oleh karena derajat efektifitas hukum ditentukan oleh taraf kepatuhan warga masyarakat terhadap hukum, ${ }^{30}$ termasuk para penegaknya. Dikenal suatu asumsi, bahwa taraf kepatuhan hukum yang tinggi, merupakan suatu indikator berfungsinya sistem hukum dan berfungsinya hukum merupakan indikator hukum tersebut mencapai tujuannya, yaitu mengusahakan atau mempertahankan kedamaian dalam pergaulan hidup. ${ }^{31}$

Penegakan hukum sertifikasi dan labelisasi produk halal berarti penegakan yang didasarkan pada tata hukum (tertulis), kaidah, dan jalinan nilai-nilai mengenai sertifikasi dan labelisasi produk halal terhadap produsen atau para pihak yang tidak mematuhi hukum yang berlaku, ${ }^{32}$ tidak bertanggungjawab dan bahkan memenuhi sifat melawan tatanan hukum. Demikian pula, norma hukum yang dipositifkan dan dirumuskan secara tertulis ke dalam rumusan pasal-pasal peraturan perundang-

${ }^{28}$ Ibid., hlm. 4

${ }^{29}$ Satjipto Rahardjo, Membedah Hukum Progresif, KOMPAS, Jakarta, 2006, hlm. 11.

${ }^{30}$ Untuk menghindari kesimpangsiuran dan kesalahfahaman dalam memaknai penegakan hukum, maka peneliti memposisikan hukum dalam hal ini sebagai tata hukum (tertulis), kaidah, dan jalinan nilai-nilai.

${ }^{31}$ Soerjono Soekanto, Penegakan Hukum, Bina Cipta, Bandung, 1983, hlm. 62-63.

${ }^{32}$ Secara sosiologis, dasar kepatuhan seseorang terhadap hukum disebabkan antara lain: diindoktrinir untuk berbuat mematuhi kaidah-kaidah hukum, mengalami proses sosialisasi, watak kecenderungan manusia untuk hidup pantas dan teratur, dan karena kepatuhan itu sendiri sebagai salah satu sarana untuk mengadakan identifikasi dengan kelompok. Selanjutnya bandingkan dengan Esmi Warassih, Pranata Hukum: Sebuah Telaah Sosiologis, (ed. Karolus Kopong Medan dan Mahmutarom HR), Suryandaru Utama, Semarang, 2005, hlm. 207-208. 
undangan harus ditaati oleh masyarakat. Oleh sebab itu, norma hukum harus mengandung nilai keadilan, nilai kepastian, dan nilai kegunaan.

Upaya penegakan hukum dan perlindungan hak konsumen terhadap sertifikasi dan labelisasi produk halal harus senantiasa diiringi dengan sistem pengendalian sosial, ${ }^{33}$ yang dapat dilakukan oleh individu terhadap individu lainnya atau dilakukan individu terhadap suatu kelompok tertentu, atau suatu kelompok terhadap kelompok lainnya, atau oleh suatu kelompok terhadap individu. ${ }^{34}$ Sistem pengendalian sosial bertujuan mencapai keserasian dan kedamaian antara stabilitas dengan perubahan dalam masyarakat. ${ }^{35}$ Sedangkan alat yang digunakan untuk pengendalian sosial dalam hal penegakan hukum dan perlingan hak konsumen terhadap sertifikasi dan labelisasi produk halal yang paling utama adalah kepatuhan pelaku usaha dan kesadaran konsumen (consumer behavior). Apabila kedua alat pengendali sosial tersebut kurang berfungsi, maka hukum dapat dipergunakan sebagai sarana pengaturan yang akan dapat mengisi kekurangan yang ada. Sebab, apabila hukum digunakan pada terminal pertama dan ternyata tidak efektif, maka secara asumtif kewibawaan hukum akan merosot dan tidak ada alternatif lain yang akan dapat dipergunakan. ${ }^{36}$

Satjipto Rahardjo menyatakan bahwa para penegak hukum perlu memanfaatkan hukum progresif, ${ }^{37}$ karena memuat banyak dimensi: 1) dimensi dan faktor manusia sebagai pelaku dalam penegakan hukum progresif. Idealnya, mereka terdiri dari generasi baru profesional hukum yang memiliki visi dan filsafat yang mendasari penegakan hukum progresif, tidak liberal, tetapi lebih cenderung ke arah visi komunal. Kepentingan dan kebutuhan bangsa lebih diperhatikan daripada "bermain-main" dengan pasal, doktrin dan prosedur. 2) kebutuhan akan

33Pengendalian sosial diartikan peneliti sebagai pengawasan oleh masyarakat terhadap cara bekerjanya pranata hukum sertifikasi dan labelisasi produk halal yang masih dalam keadaan parsial dan tersebar dalam berbagai Undang-undang. Tentu saja pranata hukum tersebut dilaksanakan oleh pihak pemerintah beserta aparaturnya.

${ }^{34}$ Soerjono Soekanto, Penegakan Hukum, Op. Cit., hlm. 10.

${ }^{35}$ Soerjono Soekanto, Penegakan Hukum, Ibid., hlm. 11. Menurutnya, sistem pengendalian sosial dapat bersifat preventif atau represif, atau kedua-duanya. Prevensi merupakan suatu usaha pencegahan terhadap terjadinya gangguan pada keserasian antara ketertiban dengan ketentraman. Usaha yang represif bertujuan untuk untuk mengembalikan keseimbangan yang pernah mengalami gangguan. Usaha pencegahan dapat dilakukan melalui proses sosialisasi, pendidikan formal, informal dan seterusnya.

${ }^{36}$ Bandingkan dengan Soerjono Soekanto, Penegakan Hukum, Ibid., hlm. 13.

${ }^{37}$ Dengan memanfaatkan hukum progresif akan muncul wajah hukum baru yang dinamis meskipun harus melakukan penafsiran. Di mana penafsiran adalah pemberian makna terhadap teks peraturan dan karena itu tidak boleh berhenti pada pembacaan harfiah saja. Dengan cara seperti itu hukum menjadi progresif karena bisa melayani masyarakatnya. Lihat Satjipto Rahardjo, Hukum dan Jagat Ketertiban, UI Press, Jakarta, tt., hlm. 172. 
kebangunan di kalangan akademisi, intelektual dan ilmuwan serta teoritisi hukum Indonesia. ${ }^{38}$

Dalam rangka penegakan hukum dan perlindungan hak terhadap sertifikasi dan labelisasi produk halal, terdapat beberapa hal yang signifikan berikut ini: pertama, Unsur dan Sistem Penegakan Hukum dan Perlindungan Hak. Faktor-faktor nonhukum, termasuk kultur, seringkali membuat adanya perbedaan penegakan hukum antara masyarakat yang satu dengan masyarakat lainnya. ${ }^{39}$ Upaya penegakan hukum dan perlindungan hak akan berfungsi dengan baik, manakala terjadi keserasian dalam hubungan antara empat faktor yang saling berkaitan secara erat, yakni: hukum atau peraturan itu sendiri, mentalitas petugas yang menegakkan hukum, fasilitas yang diharapkan untuk mendukung pelaksanaan hukum, dan budaya hukum/kesadaran hukum. ${ }^{40}$ Kedua, Faktor Kaidah Hukum. Ditemukan ketidakcocokan dalam peraturan perundang-undangan mengenai bidang kehidupan tertentu. Kemungkinan lainnya adalah ketidakcocokan antara peraturan perundang-undangan dengan hukum tidak tertulis atau hukum kebiasaan. Kadangkala ada ketidakserasian antara hukum tercatat dengan hukum kebiasaan. ${ }^{41}$ Undang-Undang tentang Pangan memberikan kesan longgar kepada pelaku usaha selama tidak terjadi kasus maka tidak perlu label/tanda halal. Karena itu hadirnya UUJPH diharapkan dapat memberikan perlindungan hak dan penegakan hukum sertifikasi dan labelisasi produk halal. Namun, harus segera diterbitkan Peraturan Pemerinah sebagai aturan pelaksanaannya. Ketiga, Faktor Penegak Hukum. Penegakan hukum dan perlindungan hak, ${ }^{42}$ peran, fungsi dan posisi penegak hukum sangat sentral dan menentukan. Penegak hukum itu antara lain mencakup hakim, polisi, jaksa, pembela, petugas lembaga pemasyarakatan.

\footnotetext{
${ }^{38}$ Sifat obyektif ini sebagai solusi dari pengawasan dan penegakan hukum termasuk sertifikasi restoran di Indonesia yang masih lemah bila dibanding dengan negara lain Lihat Satjipto Rahardjo sebagaimana dalam Khudzaifah Dimyati (ed.), Sosiologi Hukum: Perkembangan Metode dan Pilihan Masalah, Universitas Muhamadiyah Surakarta Press, Surakarta, 2002, hlm. ix.

${ }^{39}$ Esmi Warassih, Pranata Hukum: Sebuah Telaah Sosiologis..., Op. Cit., hlm., 79

${ }^{40}$ Bandingkan dengan Soerjono Soekanto, Penegakan Hukum, Binacipta, Bandung, 1983, hlm. 15. Selanjutnya lihat pula Liliana Tedjosaputro, Etika Profesi dan Profesi Hukum, Aneka Ilmu, Semarang, 2003, hlm. 66-72.

${ }^{41}$ Soerjono Soekanto, Penegakan Hukum..., Ibid., hlm. 15.

${ }^{42}$ Penegak hukum adalah pihak-pihak yang membentuk maupun menerapkan hukum. Faktor penegak hukum untuk Indonesia khususnya dilihat mentalitas dan kepribadian penegak hukumnya, karena ada kecenderungan di kalangan masyarakat untuk mengartikan hukum sebagai petugas atau penegak hukum, hukum diidentikkan dengan perilaku nyata petugas. Secara konsep, mentalitas atas kepribadian mencakup unsur-unsur pola interaksi sosial, sistem nilai-nilai yang dianut, pola berfikir, sikap, pola perilaku, sistem kaidah-kaidah atau norma-norma. Lihat Liliana Tedjosaputro, Etika Profesi dan Profesi Hukum, Aneka Ilmu, Semarang, 2003, hlm. 66-72.
} 
Apabila peraturan perundang-undangan sudah baik, akan tetapi mental penegak hukum kurang baik, maka akan terjadi gangguan pada sistem penegakan hukum. ${ }^{43}$ Sehingga dibutuhkan penegak hukum yang memiliki integritas moral yang tinggi. Integritas moral penegak hukum erat sekali kaitannya dengan konsep tanggungjawabnya, terutama sekali tanggung jawab para pelaku dalam proses sertifikasi dan labelisasi produk halal tersebut. Integritas mereka merupakan benteng terakhir sebagai harapan untuk terwujudnya supremasi (penegakan) hukum. ${ }^{44}$

Menyikapi kondisi di atas, Majelis Ulama Indonesia berpandangan bahwa perlindungan hak dan terutama penegakan hukum (law enforcement) sertifikasi dan labelisasi produk halal masih belum maksimal di kalangan aparat penegak hukum, sehingga hal itu dapat menimbulkan anarkhi. ${ }^{45}$ Unsur perlindungan hak oleh para penegak hukum dibutuhkan sebuah kejujuran dan etika, agar pengawasan dan penegakan hukumnya berhasil dan efektif. Perlindungan hak dan penegakan hukum sertifikasi dan labelisasi produk halal secara jujur sangat dibutuhkan untuk kepentingan para pihak, yakni pelaku usaha dan konsumen. Keterpaduan tugas di bidang perlindungan hak sangat tergantung pada kemampuan aparatur negara untuk menghindari timbulnya ekses yang tidak diharapkan. ${ }^{46}$

Sandra Mathison menyatakan bahwa jika penegak hukum diibaratkan sebagai jasa penilai (evaluator), maka mereka harus memposisikan dirinya sebagai pihak yang memiliki integritas moral yang baik, memegang etika profesi secara sungguhsungguh, dan memegang komitmen tinggi terhadap etika (ethics) dan garis-garis panduan secara jujur. ${ }^{47}$ Namun demikian, menurutnya, persoalan etika bagi evaluator tersebut bergantung pada integritas yang dimiliki, yang sangat dipengaruhi oleh perbedaan politik, filosofi, dan metodologi, sehingga penampilannya ada penegak (evaluator) yang cermat dalam melibatkan stakeholder, namun ada yang tidak sama sekali.48 Mengingat fungsinya sebagai evaluator, maka para pemangku kepentingan dalam proses sertifikasi dan labelisasi

\footnotetext{
${ }^{43}$ Soerjono Soekanto, Penegakan Hukum..., Op. Cit., hlm. 15.

${ }^{44}$ Bandingkan dengan A. Qodri Azizy, Hukum Nasional: Eklektisisme Hukum Islam dan Hukum Umum, Teraju, Jakarta, 2004, hlm. 224.

45 Rekomendasi/Taushiyah Musyawarah Nasional VII Majelis Ulama Indonesia, sebagaimana dalam Himpunan Keputusan Musyawarah Nasional VII Majelis Ulama Indonesia, 2005, hlm. 80

${ }^{46}$ Departemen Agama, Petunjuk Teknis....Op. Cit., hlm. 459.

${ }^{47}$ Sandra Mathison, (ed.), Encyclopedia of Evaluation, Sage Publications, New Delhi, 2005, hlm. 131.

${ }^{48}$ Ibid.
} 
produk halal ini harus memenuhi prinsip ${ }^{49}$ sebagai orang yang profesional, komunikatif, proporsional berstandar dan efektif (systematic inquiry), menunjukkan tanggungjawabnya secara penuh, dan memiliki keterampilan serta menguasai betul bidang tugas (competence). Di samping itu, juga perlu memiliki integritas dan jujur (integrity and honesty), menghargai pihak lain (respect for people), dan bertanggungjawab terhadap bidang tugasnya demi kesejahteraan umum (responsibilities for general and public welfare). 50

Keempat, Faktor fasilitas yang digunakan penegak hukum. Elemen pendukung pelaksanaan hukum adalah para penegak hukum itu sendiri. Kalau peraturan perundang-undangan sudah baik dan juga mentalitas penegaknya baik, akan tetapi fasilitas kurang memadai (dalam ukuran tertentu), maka penegakan hukum tidak akan berjalan dengan semestinya. ${ }^{51}$ Misalnya kasus oplos daging haram mengundang kecurigaan, adanya motif jahat di balik merebaknya dendeng/abon babi berlebel halal tersebut. Dengan demikian, tanggung jawab pemerintah untuk melindungi keyakinan dan kepentingan konsumen mayoritas muslim di negeri ini dinilai masih rendah. ${ }^{52}$ Lemahnya penegakan hukum dan jaminan mengenai produk halal dari pemerintah, bukan hal baru, dan jelas merugikan konsumen muslim. Kasus lemak babi (1988), Sprite (1996), sapi gelonggongan (1999-2002), Ajinomoto (2001), ayam tiren/mati (2003) begitu mudah dilupakan. ${ }^{53}$

Hasil pertemuan ulama III Komisi Fatwa Majelis Ulama Indonesia (MUI) pada 2009 yang menetapkan fatwa mewajibkan pemerintah mengawasi kehalalan sebuah produk. Keputusan Ijtima' Ulama Komisi Fatwa se-Indonesia III tentang masalah Qanuniyyah (Hukum dan Perundang-undangan), menegaskan bahwa harus ada pengaturan yang tegas, jelas dan efektif mengenai pengawasan kehalalan produk, baik produk dalam negeri maupun produk luar negeri. ${ }^{54}$

${ }^{49}$ Lihat Ibid., hlm. 179.

${ }^{50}$ Namun, undang-Undang tentang Pangan dan Perlindungan Konsumen, ketentuan tentang halal hanya bersifat opsional atau sukarela, tidak merupakan keharusan sehingga tidak bersifat imperatif. Pengawasan tentang hal tersebut juga sangat lemah.

51 Soerjono Soekanto, Penegakan Hukum..., Op. Cit., hlm. 15.

${ }^{52}$ Terlintas jawaban Rumah Potong Hewan pemerintah dalam versi pemerintah telah halal dan aman, sehingga tidak perlu lagi sertifikasi halal dari MUI, sehingga wajar saja jika faktor tersebut menjadi penyebab merebak produk abon/dendeng babi yang berlebel halal tapi haram.

${ }^{53}$ Bahkan hingga saat ini menurut Direktur Lembaga Pengkajian Pangan, Obat-Obatan, dan Kosmetika Majelis Ulama Indonesia (LPPOM MUI) sekitar 90 persen rumah potong hewan (RPH) milik pemerintah di seluruh Indonesia tak bersertifikat halal.

${ }^{54}$ MUI, Keputusan Ijtima’ Ulama Komisi Fatwa III Tahun 2009, hlm. 92. 
Pencantuman label halal pada produk yang terbukti mengandung babi atau turunannya merupakan pembohongan publik dan bertentangan dengan peraturan yang ada, yaitu UU No. 18 Tahun 2012 tentang Pangan, UU No. 8 Tahun 1999 tentang Perlindungan Konsumen, Peraturan Pemerintah No. 69 tentang Label dan Iklan Pangan, Kepmenkes No. 924/Menkes/sk/VII/1996, tentang keharusan adanya peringatan yang jelas pada produk yang mengandung bahan berasal dari babi, serta SKB Menag dan Menkes No. 427/Menkes/SKB/VII/1985 dan No 68/1985 khususnya Pasal 2.55 Dan terlebih UUJPH itu sendiri.

Kelima, faktor budaya hukum masyarakat. Kesadaran hukum, kepatuhan hukum dan perilaku warga masyarakat juga menentukan di dalam praktik perlindungan hak dan penegakan hukum. ${ }^{56}$ Jika dianalisis, setidaknya ada tiga penyebab; 1) keyakinan konsumen muslim terkait wajibnya mengonsumsi produk halal belum diikuti konsistensinya memilih produk bersertifikat halal standar. Sebagai konsumen, kita sering menjadikan harga murah sebagai penentu pilihan; 2) Produsen sering menganggap produknya tidak memakai bahan haram. Dugaan ini belum tentu benar karena banyak bahan tambahan yang berpotensi haram;3) Aspek yuridis, sertifikasi halal di Indonesia baru merupakan pilihan, belum menjadi kebutuhan, baik bagi konsumen mapun pelaku usaha atau produsen.

Pasal 1 angka (1) UU No. 8 Tahun 1999 tentang Perlindungan Konsumen. Selanjutnya disingkat UUPK merumuskan bahwa Perlindungan Konsumen adalah segala upaya yang menjamin adanya kepastian hukum untuk memberi perlindungan kepada konsumen. Meski undang-undang ini disebut sebagai UUPK, namun bukan berarti kepentingan pelaku usaha tidak ikut menjadi perhatian, teristimewa karena keberadaan perekonomian nasional banyak ditentukan oleh para pelaku usaha. Pasal 1 angka (2) UUPK menegaskan, Konsumen adalah setiap orang pemakai barang dan/atau jasa, yang tersedia dalam masyarakat, baik bagi kepentingan diri sendiri, keluarga, orang lain, maupun makhluk hidup lain dan tidak untuk diperdagangkan.

\footnotetext{
${ }^{55}$ SKB Menag dan Menkes No 427/Menkes/SKB/VII/1985 dan No 68/1985 pasal 2 dinyatakan bahwa produsen yang mencantumkan tulisan "halal" pada label atau penandaan makanan produknya bertanggungjawab terhadap halalnya makanan tersebut bagi pemeluk agama Islam. Kasus di atas menunjukkan rendahnya kinerja pemerintah dalam melakukan fungsi pengawasan.

56 Bandingkan dengan Soerjono Soekanto, Penegakan Hukum..., Op. Cit., hlm. 15.
} 
Demikian pula istilah "Pelaku Usaha" sebagai definisi yuridis formal dapat dilihat pada Pasal 1 ayat (3) UUPK, yaitu: "Setiap perseorangan atau badan usaha, baik yang berbentuk badan hukum maupun bukan badan hukum yang didirikan dan berkedudukan atau melakukan kegiatan dalam wilayah hukum negara Republik Indonesia, baik sendiri maupun bersama-sama melalui perjanjian penyelenggaraan kegiatan usaha dalam berbagai bidang ekonomi".

Istilah perlindungan konsumen berkaitan dengan perlindungan hukum. Perlindungan hukum konsumen sesunggguhnya identik dengan perlindungan yang diberikan hukum terhadap hak-hak konsumen. ${ }^{57}$ Dalam Pasal 4 dan 5 UUPK menegaskan hak-hak dan kewajiban konsumen. Oleh karena itu, sengaja judul makalah ini saya tetapkan Perlindungan dan Penegakan Hukum Sertifikasi dan Labelisasi Produk Halal. Sejalan pula dengan maksud salah satu asas hukum perdata, yaitu asas perlindungan hak.

Muhammad Alim;58 Maksud asas perlindungan hak artinya semua hak yang diperoleh dengan cara yang halal, menurut hukum Islam harus dilindungi. Pihak lain tidak boleh mengambilnya tanpa hak. Kalau ada yang melanggar hak-hak itu maka pemegang hak dapat menuntut pengembalian hak itu kepadanya atau meminta ganti kerugian dari pihak yang melanggar tersebut.

Menurut Satjipto Rahardjo,59 bahwa perlindungan hukum adalah memberikan pengayoman kepada hak asasi manusia yang dirugikan orang lain dan perlindungan tersebut diberikan kepada masyarakat agar mereka dapat menikmati semua hak-hak yang diberikan oleh hukum. Lebih lanjut dikatakan Satjipto, bahwa Hitam putihnya penegakan hukum di suatu Negara sangat tergantung pada sepak terjang aparat penegak hukum (polisi, jaksa, dan hakim). Adakah mereka bisa menghadirkan hukum sebagaimana roh dan substansi keberadaan hukum, atau justru mereka menjadi variabel penentu suburnya penegakan hukum yang membelengu masyarajat?60

Mengubah kultur individual menjadi kolektif dalam penegakan hukum memang bukan hal mudah. Sudah puluhan, hampir seratus tahun dunia penegakan

\footnotetext{
57 Tim Penyusunan Kamus dan Pengembangan Bahasa, Op. Cit., hlm. 16.

${ }^{58}$ Muhammad Alim, Asas-Asas Negara Hukum Modern dalam Islam, LKiS, Yogyakarta, 2010, hlm. 379-380.

${ }^{59}$ Satjipto Rahardjo, Konsep Hukum Progresif, Genta Publishing, Yogyakarta, 2009, hlm. 20.

${ }^{60}$ Satjipro Rahardjo, Penegakan Hukum Progresif, KOMPAS, Jakarta, 2010, hlm. IX-X.
} 
hukum (administration of justice) di Indonesia dikuasai oleh pikiran dan kultural liberal.61 Selanjutnya Satjipto menegaskan, bahwa kultur liberal menempatkan unsur penegakan hukum pada posisi berhadapan demi menjaga dan melindungi kemerdekaan individu. Kita mengenalnya dengan sebutan check and balance.62 Kehadiran UUJPH jika tidak segera disusul dengan dikeluarkan Peraturan Pemerintah sebagai pelaksanaan dari UUJPH ini akan terasa 'hambar'- kurang geregetnya dalam upaya penegakan hukum dan perlindunan hak konsumen sertifikasi dan labelisasi produk halal yang sangat didambakan terutama umat Islam atau kaum Muslimin yang ingin mengkonsumsi makanan yang halal.

Menurut Jazuni ${ }^{63}$ bahwa setiap Muslim yang taat pasti berkeinginan untuk melaksanakan hukum Islam sebagai kewajiban agama. Wujud ketaatan itu bukan hanya melaksanakannya dalam kehidupan pribadi saja, melainkan juga mendakwahkannya kepada orang lain. Salah satu bentuk dakwah itu adalah memperjuangkan hukum Islam agar menjadi (bagian dari) hukum nasional sungguhpun mengenai hal ini belum ada kesamaan pendapat dan sikap di kalangan Islam sendiri. Lebih lanjut dikatakan Jazuni bahwa memperjuangkan, memahami, dan melaksanakan hukum Islam dalam konteks hukum nasional memerlukan penyesuaianpenyesuaian sesuai dengan hasil ijtihad setempat, sehingga ada istilah "fikih lokal". ${ }^{64}$

Setelah mempertimbangkan beberapa unsur beserta faktor-faktor yang mempengaruhinya di atas, lantas dapatkah penegakan hukum dan perlindungan hak konsumen terhadap sertifikasi produk halal begitu saja dijalankan? Tampaknya sebagus apapun piranti yang tersedia (apalagi dalam kenyataannya piranti hukum itu sendiri sering ditemukan bermasalah), tak akan dapat berjalan efektif tanpa didukung sistem yang baik dan kuat.

Itu sebabnya, sistem penegakan hukum dan perlindungan hak yang ideal dalam pelembagaan sertifikasi halal adalah yang dilakukan secara kolektif baik oleh pemerintah maupun masyarakat. Ada koordinasi lintas kementerian dan lembaga. Namun setidaknya, pelaksanaan perlindungan dan penegakan hukum perlu dilakukan upaya pengawasan oleh pemerintah dapat melalui 3 sistem

${ }^{61}$ Satjipto Rahardjo, Membedah Hukum Progresif, Op. Cit., hlm. 143.

${ }^{62} \mathrm{Ibid}$.

${ }^{63}$ Jazuni, Legislasi Hukum Islam di Indonesia, Citra Aditya Bakti, Bandung, 2005, hlm. 5.

${ }^{64}$ Ibid. 
pengawasan, yakni: pertama, sistem pengawasan preventif. Sistem pengawasan ini dilakukan secara dini terhadap produk pangan halal, antara lain berupa kegiatan pendaftaran. Dengan mengoptimalkan sistem preventif, penyelewengan sertifikasi halal dapat diminimalisir sejak dini. Sehingga harapannya, potensi lembaga penegak hukum dapat berjalan secara maksimal, efektif dan efisien. Kedua, sistem pengawasan khusus. Sistem pengawasan khusus ini maksudnya adalah pengawasan aktif terhadap kasus pangan, obatan-obatan dan kosmetika halal yang dapat mengakibatkan dampak yang luas, yaitu tidak saja dalam segi kesehatan tetapi juga dalam segi sosial dan ekonomi. Ketika ditemukan tanda-tanda yang menunjukkan adanya kasus tertentu penyelewengan sertifikasi dan/atau labelisasi halal di lapangan, maka sistem ini mendorong penegak hukum menanganinya dengan tindakan yang spesifik berdasar pada kekhususan pelanggaran yang dilakukan. Ketiga, sistem pengawasan insidental. Sistem pengawasan insidental merupakan proses pengawasan yang dilakukan pihak penegak hukum terhadap keamanan dan keselamatan pangan halal yang dilakukan dengan cara inspeksi mendadak (sidak). Memang Pasal 51 UUJPH telah mengatur ketentuan mengenai pengawasan ini, akan tetapi masih memerlukan peraturan perundang-undangan sebagaimana ditegaskan dalam ayat (2)-nya.

Ketiga sistem di atas, selain dilakukan oleh aparat penegak hukum, perlu juga melibatkan peran serta masyarakat dan lembaga yang berkompeten terutama mengenai persoalan halal-haram, representasi mayoritas penduduk muslim, dan sekaligus lembaga yang mendapat pengakuan pemerintah dalam rangka menegakkan hukum UUJPH, upaya perlindungan dan penegakan hukum khususnya sertifikasi dan labelisasi produk halal. UUJPH juga telah mengatur ketentuan peran serta masyaakat dalam penyelenggaraan JPH sebagaimana ditegaskan dalam Pasal 53 UUJPH. Namun, ketentuan lebih lanjut mengenai tata cara peran serta masyarakat diatur dalam Peraturan Menteri.

\section{Penutup}

Berdasarkan uraian di atas dapat disimpulkan bahwa: pertama, UU RI No. 33 Tahun 2014 tentang Jaminan Produk Halal (UUJPH) telah mengatur mengenai 
penyelenggaraan Jaminan Produk Halal (JPH). Untuk penyelenggaraan JPH dibentuk Badan Penyelengggara Jaminan Produk Halal (BPJPH) yang berkedudukan di bawah dan bertanggung jawab kepada Menteri Agama. BPJPH menetapkan Lembaga Pemeriksa Halal (LPH) untuk melakukan pemeriksaan dan/atau pengujian kehalalan Produk. Kemudian LPH menyerahkan hasil pemeriksaan dan/atau pengujian kehalalan Produk kepada BPJPH. Selanjutnya BPJPH menyampaikan hasil pemeriksaam dan/atau pengujian kehalalan Produk kepada Majelis Ulama Indonesia (MUI) untuk memperoleh penetapan kehalalan Produk.

Kedua, beberapa faktor yang menyebabkan para pelaku usaha menunda melakukan sertifikasi halal atas produk-produk mereka: (i) UUJPH tersebut belum bisa dilaksanakan secara operasional sebab Peraturan Pemerintah (PP) yang tidak kunjung dikeluarkan. (ii) BPJPH yang merupakan amanat UUJPH juga belum didirikan. Padahal BJPH inilah yang menjadi garda terdepan dalam penyelenggaraan JPH. Hingga saat ini pendirian BPJH masih sangat samar. (iii) pelaku usaha merasa kesulitan untuk menyertifikasi beberapa jenis produk mereka, misalnya produk farmasi. Kesulitan produk farmasi yang mengimpor bahan baku dari luar negeri. (iv) kesadaran masyarakat selaku konsumen terhadap produk halal belum begitu baik.

\section{Daftar Pustaka}

Alim, Muhammad, Asas-Asas Negara Hukum Modern dalam Islam, LKiS, Yogyakarta, 2010.

Azizy, A. Qodri, Hukum Nasional: Elektisisme Hukum Islam dan Hukum Umum, Teraju, Jakarta, 2004.

Departemen Agama, Petunjuk Teknis Pedoman Sistem Produksi Halal, Jakarta, Departemen Agama RI, 2003.

Sistem Jaminan Halal, Jakarta, Depertemen Agama RI, 2003.

Sistem Prosedur Penetapan Fatwa Produk Halal MUI, Jakarta : Departemen Agama RI, 2003.

Dimyati, Khudzaifah, (ed) Sosiologi Hukum: Perkembangan Metode dan Pilihan Masalah, Universitas Muhammadiyah Surakarta Press, Surakarta, 2002.

Jazuni, Legislasi Hukum Islam di Indonesia, Citra Adiyta Bakti, Bandung, 2005.

Kelsen, Hans, Teori Hukum Murni dasar-dasar Ilmu Hukum Normatif, (Terjemahan Raisul Muttaqien, Nusa Media, Bandung, 2008. 
LPPOM MUI, Panduan Umum Sistem Jaminan Halal LP-POM MUI, LPPOM MUI, Jakarta, 2008.

MD, Moh. Mahfud, Politik Hukum di Indonesia, LP3ES, Jakarta, 1998.

Mashudi, Konstruksi Hukum dan Respon Masyarakat Terhadap Sertifikasi Produk Halal, Universitas Diponegoro, Semarang, 2011.

Mathison, Sandra, Realistic Socio Legal Theory, Clarendom, Oxford, 1997.

Miru, Ahmad, dan Sutarno Yodo, Hukum Perlindungan Konsumen, PT. Raja Grafindo Persada, Jakarta, 2004.

Rahardjo, Satjipto, Hukum dan Jagat Ketertiban, UI Press, Jakarta, Tanpa Tahun. , Membedah Hukum Progresif, KOMPAS, Jakarta, 2006. Konsep Hukum Progresif, Genta Publishing, Yogyakarta, 2009.

Soekanto, Soerjono, Penegakan Hukum, Bina Cipta, Bandung, 1983.

Tedjosaputro, Liliana, Etika Profesi dan Etika Hukum, Aneka Ilmu, Semarang, 2003.

Warassih, Erni, Peranata Hukum: Sebuah Telaah Sosiologi, Suryandaru Utama, Semarang, 2005.

Tim Penyusun Kamus dan Pengembangan Bahasa, Kamus Besar Bahasa Indonesia. Cetakan Kesepuluh, Depdikbud, Balai Pustaka, Jakarta, 1998.

Undang-Undang Dasar Negara Republik Indonesia Tahun 1945.

Undang-Undang Nomor 18 Tahun 2012 tentang Pangan (Lembaran Negara Nomor 227, Tambahan Lembaran Negara Nomor 5360).

Undang-Undang Nomor 8 Tahun 1999 Tentang Perlindungan Konsumen (Lembaran Negara Nomor 42, Tambahan Lembaran Negara Nomor 3821).

Undang-Undang Nomor 33 Tahun 2014 Tentang Jamina Produk Halal (Lembaran Negara Tahun 2014 Nomor 295).

LP POM MUI. 2009. Jurnal Halal: Menentramkan Ummat. No. 78 Th. XII.

LP POM MUI. 2011. Jurnal Halal: Menentramkan Umat. No. 88 Th. XIV.

Label Halal tanpa Sertifikat", source http://m.republika.co.id/berita/ shortlink/17092, diakses tanggal 10 Februari 2013.

"MUI Desak Pengoplosan daging sapi dengan babi ditindak", source: http:/ /www.metrotvnews.com/read/news/2012/12/14/117668/MUIDesak-Pengoplos-Daging-Sapi-dengan-Babi-Ditindak/6, di akses tanggal 12 Maret 2013.

“Bakso Oplosan Daging Babi buat Resah Warga" source: http://www.metrotvnews. $\mathrm{com} / \mathrm{read} /$ newsvideo/2012/12/14/166459/Bakso-Oplosan-Daging-BabiBuat-Resah-Warga/6, diakses tanggal 9 Mei 2013. 